\title{
Strategic Sustainable Management for Water Transmission System: A SWOT- QSPM Analysis
}

\author{
Ni Made Sumiarsih \\ Civil Engineering Department, Diponegoro University, Semarang, INDONESIA \\ sumiar1@yahoo.com \\ Djoko Legono \\ Department of Civil and Environmental Engineering, Universitas Gadjah Mada, Yogyakarta, INDONESIA \\ djokolegono@ugm.ac.id \\ Robert J. Kodoatie \\ Civil Engineering Department, Diponegoro University, Semarang, INDONESIA \\ rjkodoatie@hotmail.com
}

\begin{abstract}
In general, the problem of a water resources infrastructure, especially the raw water transmission system, is that the actual discharge is not in accordance with design discharge because of water losses along the transmission system. To restore the capacity to the design discharge, a comprehensive strategy is required. Various strategy methods have been developed especially the strategy of managing a system. This paper discusses how to analyze the comprehensive strategy with system component approach for water transmission system. The research used Klambu-Kudu Water Transmission System in Semarang, Central Java, Indonesia as a case study. Strategy analysis of Klambu-Kudu Water Transmission System utilized the modified Strength, Weakness, Opportunity, and Threats (SWOT) with Likert scale and Quantitative Strategic Planning Matrix (QSPM) method. SWOT analysis is was carried out to obtain a comprehensive strategy on each component of the water transmission system (intake, mud pouch, siphon, gutter, bridge, culvert, regulator doors, suppletion, drain pipe, and / or excavation), while the QSPM method is required to analyze the strategic priorities of component of Klambu Kudu Water Transmission System. Key factors of water transmission system performance were obtained from the discussion of experts, the management of Klambu Kudu Water Transmission System and the community. The results are a priority of strategies which are dominated by the opportunity factors to solve the problem of weakness (operation and maintenance, sedimentation, damage) and threats (water theft, destruction of buildings, flood) as well as maximizing the strengths (condition of the component, function, accessibility).
\end{abstract}

Keywords: Water transmission system, components of system, SWOT, QSPM, Likert scale

\section{INTRODUCTION}

The open-channel water transmission system will consist of various interconnected components of hydraulic structures, such as intake, mud pouch, siphon, gutter, bridge, culvert, control intake, suppletion, excavation channel and embankment channel. All these components are connected in producing a good transmission system. Thus, if the performance of transmission system experiences is decreasing, the most appropriate strategy analysis is needed to restore the function of the transmission system to fit the plan for all components of the system. Currently, the assessment method for the overall system has been widely developed, but in the maintenance management aspect. Assessment methods, the averages are used for the determination of handling strategies or handling priorities.
Diamantopoulou and Voudouris (2008) analyzed the strategy of handling urban water supply management with SWOT and AHP method. There is also research by Yavuz and Baycan (2013) with the SWOT method by Petousi, et al. (2017). The aspect studied was focusing on management system aspect, not touching the aspect of a system component. Research on infrastructure component aspect was done by Srdjevic, et al. (2012) which examined on how to determine the possible criteria for the selection of optimal reconstruction solutions of the structure of raw water intake buildings in a water resources system. Ayala and Juizo (2011) examined the implementation strategies in the IWRM case in Mozambique using the SWOT-AHP method. Research on the best type of water source to be selected in Asia Africa using the SWOT method was done by Nagara, et al. (2015). The optimal 
management analysis using the SWOT method was examined by Yavus and Baycan (2013). Research using SWOT method and Likert scale was done by Matias (2010) which discussed public responses to the management of reservoir ecosystems to support decision-making for stakeholders to manage equitable and sustainable water resources management; Michailidis, et al. (2015) examined the use of treated wastewater to improve the agricultural sector in Europe; Prisanto, et al. (2015) analyzed the institutional, financing, technical, and environmental quality aspects, in the management of the communal domestic WWTP (Wastewater Treatment Plant). In addition, research using SWOT and QSPM methods was also done by Baby (2013) in the use of SWOT and QSPM methods to support policymakers in an effort to protect coastal areas in the form of safeguard policies and regulations; Mousavizadeh, et al. (2015) and Mohammadi, et al. (2015) examined sustainable water resource management planning by analyzing the factors, to optimize water use and reduce the amount of water loss. From the previous description can be drawn the conclusion that in the realm of assessment to produce a strategy by means of quantification is used an approach to system approach and system component. A systematic approach is used to assess management issues and define strategies, while system component approaches are used to generate priority strategies for each component. In this paper, we will discuss one of the methods with component system approach (SWOT-QSPM) which will be used to determine the strategy of water transmission system with a case study of Klambu-Kudu Water Transmission System Semarang, Indonesia. In this research will analyze the handling of strategy for an aspect of infrastructure system component by using SWOT method with Likert scale and strategic priority with QSPM method. The Research Gap is shown in Figure 1.

The purpose of this study is to evaluate the function of raw water transmission system of Klambu-Kudu in accordance the function of the plan. The objectives are first to examine the strategy should be done and secondly to determine the priority of the strategy of the raw water infrastructure component

\section{RESEARCH OBJECT}

According to BBWS Pemali Juana (2015), KlambuKudu's water transmission in Central Java, Indonesia was built starting in 1991 and had 12 types of infrastructure components, namely raw water intake, Mud Bags, Siphon, Gutters, Bridges, Culverts, Regulatory Doors, Suppletion, Embankment Channel, Excavation Channel. The length of the standard Kambu Klambu water channel was $40.55 \mathrm{~km}$ stretches from Grobogan to Semarang, Central Java with a 24 $\mathrm{km}$ long of canal embankment and a $16.55 \mathrm{~km}$ excavation canal (see Figure 2).

Raw water transmission system of Klambu Kudu which the water source from Serang River has a function to supply water to Semarang city. The water intake is in Klambu in Serang river while the outlet is in Kudu water treatment plant (WTP) in Semarang city. Since has been built in 1991, this water transmission system has not been able to operate optimally. As can be seen in Figure 2, the actual discharge at Klambu intake is $1331 \mathrm{l} / \mathrm{sec}$ while the design discharge is $3000 \mathrm{l} / \mathrm{sec}$. The actual discharge in Kudu WTP is $900 \mathrm{l} / \mathrm{sec}$ while the design discharge is $1850 \mathrm{l} / \mathrm{sec}$

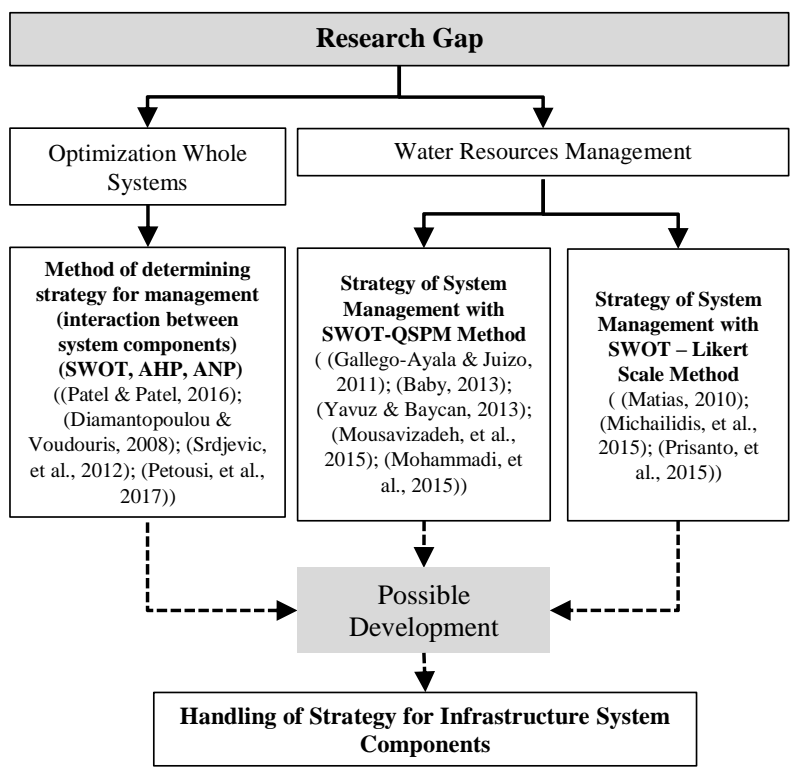

Figure 1. Research gap

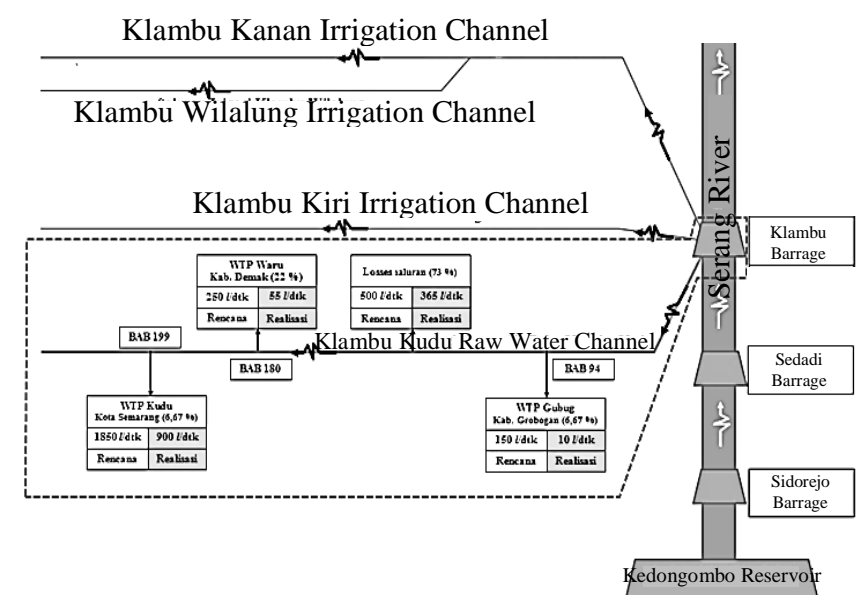

Figure 2. Scheme of the raw water system of Klambu-Kudu 
The construction process of Infrastructure of Raw Water Klambu Kudu began in 1991 and completed in 2001. Since it was operated in 2002 the channel and its components were suffered from severed damaged. A landslide of levees was often occurred due to the weather caused by inadequate care during the construction period. This causes the material of landslide entering the channel and caused sedimentation problems. Initially operated in 2002, Klambu intake was only able to deliver discharge of $200 \mathrm{l} / \mathrm{s}$ to $300 \mathrm{l} / \mathrm{sec}$. Figure 3 shows the discharge records from the beginning of the operation to 2016 . The design discharge of Klambu water intake is 3000 $1 / \mathrm{sec}$, however the actual discharge until now is only $1331 \mathrm{l} / \mathrm{sec}$.

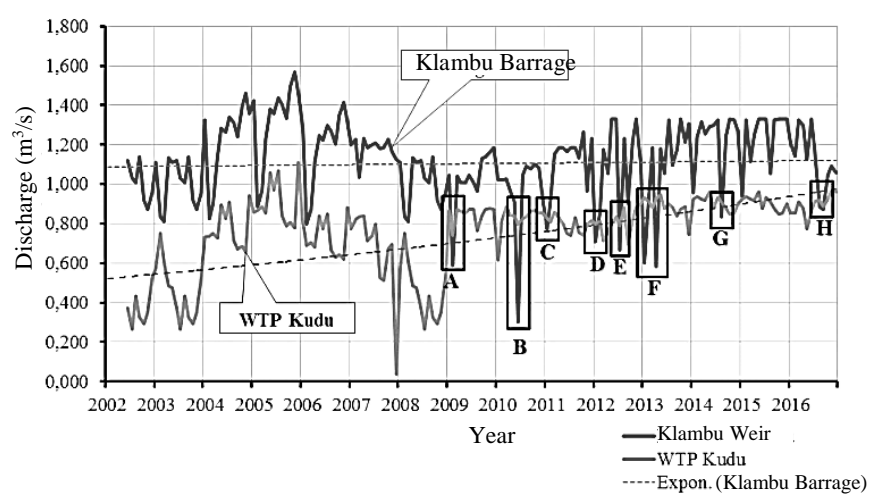

Figure 3. Discharge record graphic of Klambu Kudu dam raw water

The decreasing discharge due to Klambu Dam raw water Intake is closed because of the maintenance in the upstream of raw water or the flood happened in Serang River so that the suppletion components are operated to fulfill the need of raw water discharge. Table 1 shows the comparison between the design and the actual discharge.

Table 1. Comparison between the design and actual discharge

\begin{tabular}{llll}
\hline Opinion & $\begin{array}{l}\text { Plan } \\
(1 / \mathrm{sec})\end{array}$ & $\begin{array}{l}\text { Realization } \\
(1 / \mathrm{sec})\end{array}$ & Information \\
\hline $\begin{array}{l}\text { The raw } \\
\text { water intake } \\
\text { of Klambu }\end{array}$ & 3000 & 1331 & $44 \%$ of the plan \\
$\begin{array}{l}\text { Dam } \\
\text { Grobogan } \\
\text { Regency }\end{array}$ & 150 & 5 & $3 \%$ of the plan \\
$\begin{array}{l}\text { Demak } \\
\text { Regency }\end{array}$ & 250 & 50 & $20 \%$ of the plan \\
$\begin{array}{l}\text { Discharge } \\
\text { for villages }\end{array}$ & 250 & 5 & $5 \%$ of the plan \\
$\begin{array}{l}\text { WTP Kudu } \\
\text { Water }\end{array}$ & 1850 & 900 & $48 \%$ of the plan \\
losses & 500 & 365 & $73 \%$ of the plan \\
\hline
\end{tabular}

\section{LITERATURE REVIEW}

\subsection{SWOT Method}

SWOT stands for Strength, Weakness, Opportunities, and Threats. Strengths and weaknesses are internal factors, while opportunities and threats are external factors. SWOT is a useful tool for analyzing the situation as a whole. This approach seeks to maximize the strengths and opportunity and at the same time to minimize the weaknesses and threats. ((Coman \& Ronen, 2009); (Helms \& Nixon, 2010); (Ekmekcioglu, et al., 2011); (Srdjevic, et al., 2012); (Wang, et al., 2014); (Martínez \& Piña, 2015); (Michailidis, et al., 2015); (Budi, et al., 2016); (Jasiulewicz-Kaczmarek, 2016)). In the SWOT analysis, it is important to determine the purpose of the research. The SWOT analysis can be used for one or more of the following purposes (Rehak \& Grasseova, 2011):

a) As a basis for determining vision

b) As a basis for determining strategic objectives

c) As the basis of strategic alternatives

d) To identify critical areas

Figure 4 shows that there are eight steps to create a SWOT Matrix (David, 2011), as described below:

a) Determine the opportunity factor $(\mathrm{O})$;

b) Determine the Threats factor $(\mathrm{T})$;

c) Determine the Strength factor $(\mathrm{S})$;

d) Determine the Weakness (W);

e) Combine strength (internal) with opportunities (external), and result is as SO Strategy;

f) Combine weakness (internal) with opportunities (external), and result is a WO Strategy;

g) Combine strength (internal) with threats (external) and the results as an ST Strategy;

h) Combine weakness (internal) with threats (external) and the result is as WT Strategy.

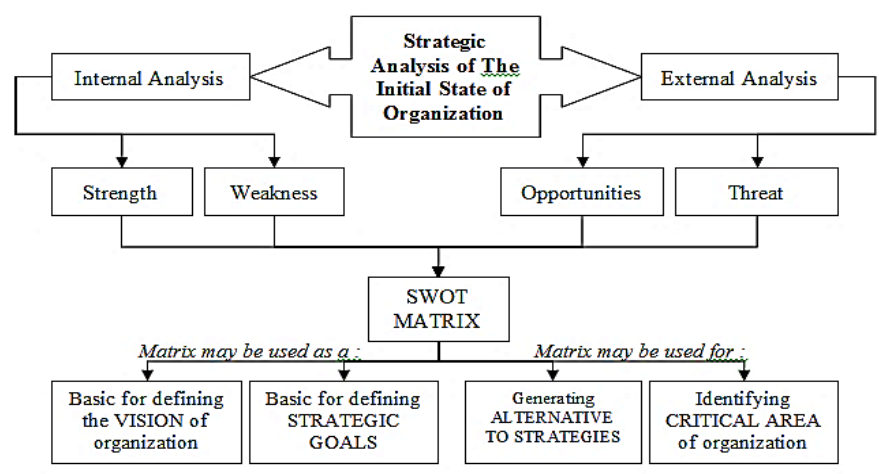

Figure 4. The framework of SWOT analysis (Rehak \& Grasseova, 2011) 
Table 2. SWOT matrix analysis (Whalley, 2010)

\begin{tabular}{lll}
\hline Opportunities & $\begin{array}{l}\text { Strengths } \\
\text { How do I use } \\
\text { these Strengths } \\
\text { to take advantage } \\
\text { of these } \\
\text { opportunities } \\
\text { (SO) }\end{array}$ & $\begin{array}{l}\text { Weakness } \\
\text { the Weaknesses } \\
\text { that prevent me } \\
\text { from taking } \\
\text { advantage of these } \\
\text { Opportunities } \\
\text { Threat }\end{array}$ \\
$\begin{array}{l}\text { How do I use my } \\
\text { Strengths to } \\
\text { reduce the } \\
\text { impact of Threats } \\
\text { (ST) }\end{array}$ & $\begin{array}{l}\text { How do I address } \\
\text { the Weaknesses } \\
\text { that will make } \\
\text { these threats a } \\
\text { reality (WT) }\end{array}$ \\
\hline
\end{tabular}

SWOT matrix analysis as can be seen in Table 2, defines the strategies to achieve the goal by maximize the driver's factors and minimize the inhibitory factors. The matrix consists of SO strategy (aggressive strategy) harnesses the power and seeks to take advantage of opportunities; ST strategies (diversification) uses force to avoid threats; WO strategies (turn around strategies) take advantage of opportunities to reduce weaknesses and WT strategies (defensive strategies) reduce weaknesses and move away from threats ((Nejad, et al., 2011); (Mousavi \& Akbari, 2012); (Malik, et al., 2013); (Sargolzaei \& Keshtegar, 2013); (Akbarpour \& Tabibian, 2015); (Aspan, et al., 2015); (Mousavizadeh, et al., 2015); (Adib \& Habib, 2016)).

Although SWOT analysis is widely used in business management, this analysis has also been successfully applied in identifying and solving problems related to water resource management. ((Kallioras, et al., 2010); (Mainali, et al., 2011); (Srdjevic, et al., 2012); (Yavuz \& Baycan, 2013); (Nagara, et al., 2015)).

\subsection{The Likert Scale}

Various measurement scales can be used to assess attitudes or opinions that are qualitative and change it to quantitative measures. This research using Likert measurement scale because this measurement is simple and easy to adopt. In general, the scale is used to measure attitudes, perceptions, values, and interests of people. The scale does not reveal success or failure, strength or weakness of the measuring object ((Sappaile, 2007); (Windiyani, 2012)). The
Likert scale initially contained five response category points that had equal distance (equidistant). The 5 (five) point model then became a typical and generic model for all types of attribute measurements ((Likert, 1932); (Sappaile, 2007); (Widhiarso, 2011); (Hartley, 2014); (Othman, et al., 2012); (Bicen, et al., 2015); (Eshaghi, et al., 2015); (Troch, et al., 2015); (Shafieyan, et al., 2017)). The use of Likert scale as a data collection tool would be much more practical, saving time and effort than other methods ((Sappaile, 2007); (Ololube, 2016); (Widiyanti, 2016)).

\subsection{QSPM Method}

QSPM is designed to determine the relative attractiveness of viable alternative strategies by examining the fundamental internal and external factors. Conceptually, QSPM determines the relative attractiveness of different strategies based on the extent to which alternative strategies will capitalize on strengths and opportunities, fix weaknesses, and avoid or reduce threats ((Ommani, 2011); (Saghaei, 2012); (Rumanti \& Syauta, 2013); (Shiehbeiki, et al., 2014); (Valiollarabieifar, et al., 2014); (David, et al., 2017); (Ghosian, et al., 2015); (Wati, et al., 2016); (Wahyuningsih, 2016); (Wijayanto, 2016)). The QSPM components in this analysis are strategic alternatives, a key factor, weight, attractiveness score and total score. The attractiveness score is defined as a numerical value indicating the relative attractiveness of each strategy in a set of designed strategy alternatives. The range of the attractiveness value is 1 $=$ unrelated, $2=$ somewhat related, $3=$ quite related and $4=$ strongly related. Total Attractive Score (TAS) value is the multiplication of the Attractive score and the Weight value on IFE analysis (Internal Factor Evaluation) and EFE (External Factor Evaluation) ((Abbasi, et al., 2016); (David, et al., 2017); (Hezarjribi \& Bozorgpour, 2017); (Rezazadeh, et al., 2017)). To perform the necessary data analysis, the main factor of QSPM comes from the IFE Matrix and EFE Matrix and the alternative strategies of the SWOT Matrix. However, not all alternative strategies should be evaluated using QSPM. Researchers should use a good intuitive assessment to choose which strategy to analyze using QSPM (Ariendi, et al., 2015). The process of SWOT-QSPM analysis shown in Figure 5. 


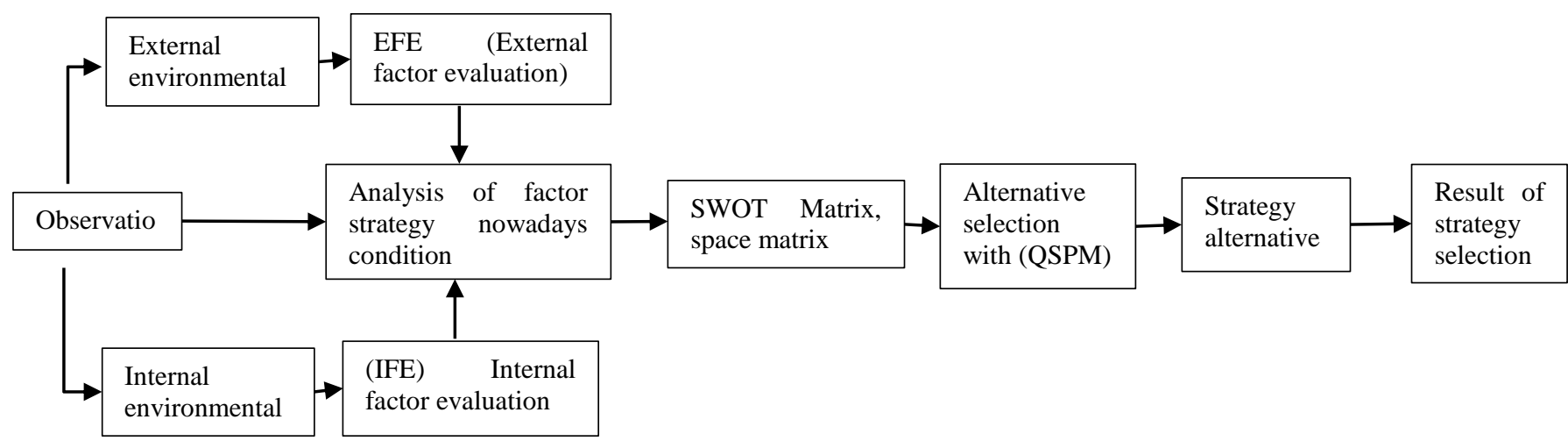

Figure 5. The process of Strategies Decision Making, Hunger and Wheelen Modified (Wati, et al., 2016)

\section{ANALYSIS PROCESS}

\subsection{Analysis of raw water transmission system}

In this study, the analysis of raw water transmission system includes components of raw water buildings such as raw water intake components, Mud Sacks, Siphon, Gutters, Bridges, Culverts, and Regulatory Doors. While the raw water channel components consist of raw sewerage components of pile type and channel type. Components of raw water channels and each component of raw water infrastructure which is located along $40.55 \mathrm{~km}$ channel have different problems, such as landslide, sedimentation and illegal water abstraction by surrounding communities. These problems lead to inappropriate discharge in the transmission system.

\subsection{SWOT Factor Analysis}

As described in the SWOT description, the factors of SWOT are internal factors (Strength and Weakness) and external factors (Opportunity and Threat). The Internal Factor Evaluation (IFE) matrix is used to analyze the internal environment of raw water infrastructure components, by evaluating strengths and weaknesses. While the External Factor Evaluation Matrix (EFE) analyzes the external factors used to evaluate opportunities and threats. Finally, after identifying the internal and external factors on the infrastructures of Klambu Kudu's raw water transmission system, the weight can be assigned to each factor, ranging from 0.0 to 1.0 , depending on the level of importance. The total number of Internal factors is 1 , as well as the total number of external factors. Zero means the least important or unrelated and one shows the most important or very related (Tehrani, 2017).

\subsection{SWOT-QSPM Analysis}

SWOT analysis on a component of infrastructure Klambu Kudu transmission system is done in all infrastructure components. Field survey and information gathering of each component of infrastructure are done together with officers from the manager in order to know the actual condition of the infrastructure component while the perception of the community and the experts are obtained by interviewing session. The interview was conducted after internal and external factor analysis were known, and the interview was done in the form of a questionnaire to the management of raw water infrastructure of Klambu Kudu. A total of 25 (twentyfive) persons consisting of the Head of the Water Unit of Klambu Kudu Standard, Administration Staff, Technical Staff, Coordinator and Deputy Area Coordinator, Foreman and Area Supervisor, and operator. The respondents were chosen because the Raw Water Management Klambu Kudu carries out the infrastructure management directly in the field every day. The questionnaire for the community along the transmission system and the experts are utilized as well. In Table 3, IFE and EFE analyzes are an example of water intake at Klambu dam. Table 4 shows the IFE analysis result of Klambu water intake. Figure 6 illustrates that Klambu water intake strategy derived from IFE and EFE analysis lies in Quadrant I with Aggressive Strategy, which means that the strategy is to optimize the internal factors of strength $(\mathrm{S})$ and the external factors of opportunity (O). 
Table 3. IFE and EFE analysis of Klambu water intake

\begin{tabular}{|c|c|c|c|c|c|}
\hline No & Key Factor & Weight & Rank & Weighted Score & \\
\hline & Strength & & & & \multirow{20}{*}{ 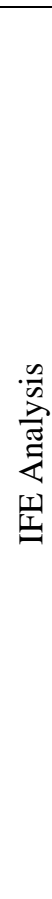 } \\
\hline 1 & Function for taking of raw water discharge & 0.05 & 5 & 0.25 & \\
\hline 2 & The building is in good condition & 0.05 & 5 & 0.25 & \\
\hline 3 & Construction material are easy to find & 0.05 & 3 & 0.15 & \\
\hline 4 & Construction method are easy to implement & 0.05 & 3 & 0.08 & \\
\hline 5 & The location of the building is easy to reach & 0.05 & 4 & 0.20 & \\
\hline 6 & Access road condition are good & 0.05 & 4 & 0.20 & \\
\hline 7 & Storage of building materials is easy and available & 0.05 & 3 & 0.08 & \\
\hline 8 & $\begin{array}{l}\text { Raw water intake has an alternative raw water intake using pump in an } \\
\text { emergency situation }\end{array}$ & 0.05 & 3 & 0.15 & \\
\hline 9 & Care and maintenance of the buildings & 0.05 & 4 & 0.20 & \\
\hline 10 & The cost of building repairs & 0.05 & 4 & 0.20 & \\
\hline \multirow[t]{3}{*}{11} & The benefits of building for the environment & 0.05 & 3 & 0.15 & \\
\hline & Total & & & 1.9 & \\
\hline & Weakness & & & & \\
\hline 1 & The location of raw water intake in the inner river bend & 0.10 & 3 & 0.30 & \\
\hline 2 & $\begin{array}{l}\text { Sediment and waste are very much in upstream of raw water intake, } \\
\text { especially in rainy season }\end{array}$ & 0.20 & 4 & 0.80 & \\
\hline 3 & The war water intake gate is still manual & 0.05 & 3 & 0.15 & \\
\hline 4 & The discharge control is still done manually & 0.05 & 3 & 0.15 & \\
\hline \multirow[t]{3}{*}{5} & Security of building is still minimum & 0.10 & 2 & 0.20 & \\
\hline & Total & 1.00 & & 1.60 & \\
\hline & Opportunity & & & & \multirow{9}{*}{ 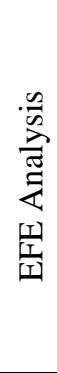 } \\
\hline 1 & Benefits for the community surrounding the building & 0.15 & 3 & 0.45 & \\
\hline 2 & Replacement of raw water intake site to reduce sediment impact & 0.30 & 4 & 1.20 & \\
\hline \multirow[t]{3}{*}{3} & Community participation around the building & 0.10 & 2 & 0.20 & \\
\hline & Total & & & 1.85 & \\
\hline & Threat & & & & \\
\hline 1 & Prone to abuse by the public with opening the gate shut & 0.20 & 3 & 0.60 & \\
\hline \multirow[t]{2}{*}{2} & Water elevation is very low in dry season & 0.25 & 4 & 1.00 & \\
\hline & Total & 1.00 & & 1.60 & \\
\hline
\end{tabular}

Table 4. IFE analysis result of Klambu water intake

\begin{tabular}{|c|c|c|c|c|c|c|}
\hline \multirow[t]{2}{*}{ Infrastructure Component } & \multicolumn{3}{|c|}{ IFE Analysis } & \multicolumn{3}{|l|}{ EFE Analysis } \\
\hline & Strength & Weakness & Difference & Opportunity & Threat & Difference \\
\hline Raw water intake & 1.90 & 1.60 & 0.30 & 1.85 & 1.6 & 0.25 \\
\hline Mud pouch & 1.68 & 2.00 & -0.33 & 1.7 & 1.75 & -0.05 \\
\hline Siphon & 1.75 & 1.65 & 0.10 & 1.7 & 1.5 & 0.20 \\
\hline Raw water gutter & 1.65 & 1.35 & 0.30 & 1.8 & 1.5 & 0.30 \\
\hline Drainage gutter & 1.70 & 2.10 & -0.40 & 1.75 & 1.8 & -0.05 \\
\hline Bridge & 1.68 & 1.25 & 0.43 & 1.63 & 2.00 & -0.38 \\
\hline SAB culvert & 1.60 & 1.80 & -0.20 & 1.78 & 1.75 & 0.02 \\
\hline Drainage culvert & 1.35 & 2.00 & -0.65 & 1.80 & 2.25 & -0.45 \\
\hline Regulatory door & 1.88 & 1.40 & 0.48 & 1.75 & 1.50 & 0.25 \\
\hline Suplesion & 2.03 & 2.00 & 0.02 & 1.68 & 2.00 & -0.33 \\
\hline The embankment channel & 2.30 & 1.85 & 0.45 & 1.9 & 2.30 & -0.40 \\
\hline Excavation channel & 1.9 & 2.40 & -0.50 & 1.90 & 2.35 & -0.45 \\
\hline
\end{tabular}

Based on IFE and EFE analysis, the following strategies for Klambu water intake as shown in Table 5. Each infrastructure component is assessed individually because the problems that occur in each infrastructure component are also different.
The results of SWOT-QSPM analysis also show different strategy results and different priorities, that is due to different problems of each component of infrastructure Klambu Kudu. SWOT analysis resulted in the strategies of each component of infrastructure. To determine the priority of strategies, the QSPM analysis was conducted. 
Table 5. SWOT strategy of the building of Klambu water intake

SWOT Strategy (SO)
a) Maintain and improve the function and condition of
the building intake, so that surrounding community
get the benefits (SOa)
b) Replacement the location of raw water intake is easy
to do, supported by location, construction materials
and easy implementation method (SOb)
c) Keep the raw water intake in good condition and
function, so it can be used easily if in an emergency
situation (SOc)
d) Regular maintenance to minimize repair costs (SOd)
e) Increasing the community participation in building
maintenance efforts (SOe)

In QSPM analysis, the value of Attractive Score (AS) is obtained by the opinion of the researcher. The strategies that have been obtained by SWOT analysis was utilizing Then Total Attractive Score (TAS) is obtained by multiplying AS and weight. The value of Sum of Total Attractive Score (STAS) indicates the rank of the priorities. The result of QSPM analysis as an example in the building of raw water intake of Klambu Kudu can be seen in Table 6.

Table 6. QSPM analysis of raw water intake buildings of Klambu-Kudu

\begin{tabular}{|c|c|c|c|c|c|c|c|c|c|c|c|}
\hline \multirow{2}{*}{ Key factor } & \multirow{2}{*}{ Weight } & \multicolumn{2}{|c|}{ SO1 } & \multicolumn{2}{|c|}{$\mathrm{SO} 2$} & \multicolumn{2}{|c|}{$\mathrm{SO} 3$} & \multicolumn{2}{|c|}{$\mathrm{SO} 4$} & \multicolumn{2}{|c|}{ SO5 } \\
\hline & & AS & TAS & AS & TAS & AS & TAS & AS & TAS & AS & TAS \\
\hline S1 & 0.05 & 4 & 0.20 & 4 & 0.20 & 4 & 0.20 & 3 & 0.15 & 1 & 0.05 \\
\hline $\mathrm{S} 2$ & 0.05 & 4 & 0.20 & 1 & 0.05 & 3 & 0.15 & 3 & 0.15 & 1 & 0.05 \\
\hline S3 & 0.05 & 2 & 0.10 & 3 & 0.15 & 2 & 0.10 & 2 & 0.10 & 2 & 0.10 \\
\hline $\mathrm{S} 4$ & 0.03 & 2 & 0.05 & 3 & 0.075 & 2 & 0.05 & 2 & 0.05 & 2 & 0.05 \\
\hline S5 & 0.05 & 2 & 0.10 & 3 & 0.15 & 2 & 0.10 & 2 & 0.10 & 2 & 0.10 \\
\hline S6 & 0.05 & 2 & 0.10 & 3 & 0.15 & 2 & 0.10 & 2 & 0.10 & 2 & 0.10 \\
\hline S7 & 0.03 & 1 & 0.03 & 2 & 0.05 & 1 & 0.025 & 2 & 0.05 & 1 & 0.025 \\
\hline S8 & 0.05 & 1 & 0.05 & 1 & 0.05 & 4 & 0.20 & 1 & 0.05 & 1 & 0.05 \\
\hline S9 & 0.05 & 3 & 0.15 & 1 & 0.05 & 3 & 0.15 & 4 & 0.20 & 3 & 0.15 \\
\hline S10 & 0.05 & 2 & 0.10 & 2 & 0.10 & 2 & 0.10 & 4 & 0.20 & 1 & 0.05 \\
\hline S11 & 0.05 & 4 & 0.20 & 1 & 0.05 & 1 & 0.05 & 2 & 0.10 & 3 & 0.15 \\
\hline W1 & 0.10 & 2 & 0.20 & 2 & 0.20 & 1 & 0.10 & 2 & 0.20 & 2 & 0.20 \\
\hline W2 & 0.20 & 4 & 0.80 & 3 & 0.60 & 3 & 0.60 & 1 & 0.20 & 1 & 0.20 \\
\hline W3 & 0.05 & 2 & 0.10 & 3 & 0.15 & 1 & 0.05 & 1 & 0.05 & 2 & 0.10 \\
\hline W4 & 0.05 & 3 & 0.15 & 3 & 0.15 & 1 & 0.05 & 3 & 0.15 & 2 & 0.10 \\
\hline W5 & 0.10 & 1 & 0.10 & 1 & 0.10 & 2 & 0.20 & 1 & 0.10 & 2 & 0.20 \\
\hline $\mathrm{O} 1$ & 0.15 & 1 & 0.15 & 1 & 0.15 & 1 & 0.15 & 1 & 0.15 & 2 & 0.30 \\
\hline $\mathrm{O} 2$ & 0.30 & 3 & 0.90 & 4 & 1.20 & 2 & 0.60 & 1 & 0.30 & 1 & 0.30 \\
\hline $\mathrm{O} 3$ & 0.10 & 2 & 0.20 & 1 & 0.10 & 1 & 0.10 & 1 & 0.10 & 4 & 0.40 \\
\hline $\mathrm{T} 1$ & 0.20 & 2 & 0.40 & 1 & 0.20 & 2 & 0.40 & 1 & 0.20 & 3 & 0.60 \\
\hline $\mathrm{T} 2$ & 0.25 & 3 & 0.75 & 1 & 0.25 & 3 & 0.75 & 2 & 0.50 & 1 & 0.25 \\
\hline \multicolumn{2}{|c|}{ STAS } & & 5.03 & & 4.18 & & 4.23 & & 3.20 & & 3.53 \\
\hline \multicolumn{2}{|c|}{ Priority } & & 1 & & 2 & & 3 & & 5 & & 4 \\
\hline
\end{tabular}

Priority of strategy of QSPM analysis of Klambu water intake can be seen in Table 7.

Table 7. Analysis result on raw water intake component of Klambu-Kudu

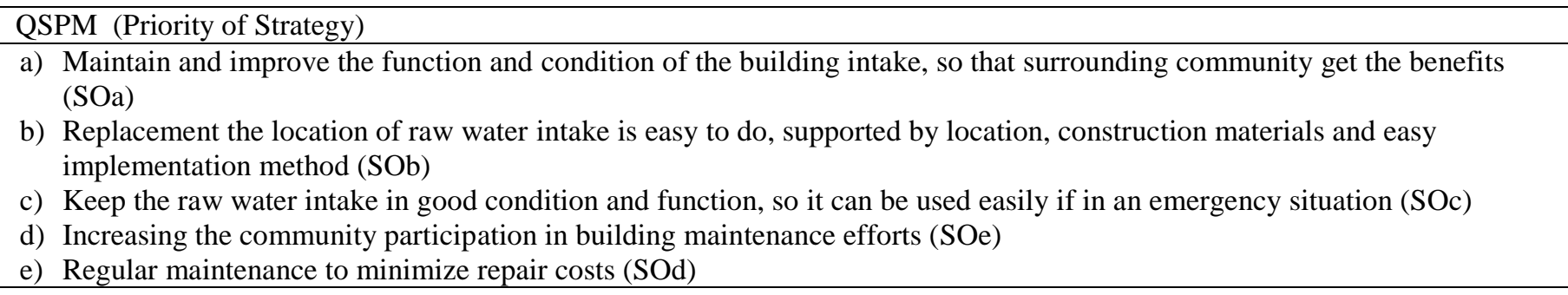

Table 8 shows the results of strategy priority analysis with the QSPM method for all components of raw water transmission of Klambu Kudu 
Table 8. QSPM result analysis for SWOT strategy of raw water infrastructure component of Klambu-Kudu

Raw Water Infrastructure QSPM (Priority of Strategy)

Component

Raw Water Intake

Infrastructure of Klambu

Kudu

Maintain and improve the function and condition of the building intake, so that surrounding community get the benefits (SOa); Replacement the location of raw water intake is easy to do, supported by location, construction materials and easy implementation method (SOb); Keep the raw water intake in good condition and function, so it can be used easily if in an emergency situation (SOc); Increasing the community participation in building maintenance efforts (SOe); Regular maintenance to minimize repair cost (SOd)

Mud Pouch of Raw Water Doing continuous flushing for flushing raw water (WTa); Construction on the banks of the river, so dike need to check and maintain regularly to avoid landslide Infrastructure of Klambu (WTc); Because it requires a large location, intensive operation and maintenance is necessary to avoid scoring based on the channel (WTb)

Siphon of Raw Water

Infrastructure of Klambu Kudu

Increasing public participation and provision of warning boards, to improve the safety of buildings (SOc); Function and condition of the building is still good, so the treatment can be done easily, and can be beneficial to the surrounding community because the well around the building is always fully filled due to rising groundwater level (SOa); Construction material from concrete, easy construction method, so the maintenance of the building can be done well and minimize maintenance cost and the longer building age (SOb)

Raw Water Gutter of

Klambu Kudu

Increasing public participation and provision of warning boards, to improve the safety of buildings (SOc); Function and condition of the building is still good, so the treatment can be done easily (SOa); Construction materials and construction method are easy to do, thus simplifying maintenance activities and minimizing maintenance costs (SOb); With the buildings, the wells of the surrounding community are always filled, because the groundwater level rises (SOd)

Drainage Gutter of Raw

Water Infrastructure of Improvement or widening dimension of the building to be able to function well especially during the rain, so rainwater that passed through drainage gutters does not overflow with raw water channel (WTc); Increased the safety of local authorities and communities to minimize the destruction of the buildings (WTa); Build access road, so buildings are easily accessible (WTb)

Klambu Kudu

Bridge of Raw Water

Infrastructure of Klambu

Kudu

Infrastructure of Klambu

Kudu

The function and condition of building is still good, thus facilitating maintenance of the building and minimizing the maintenance costs, and the public can use it for the transportation line (STa); Routine socialization and sweeping with related authorities on prohibited activities to minimize water theft action. (STc); Accessible location, construction method, easy construction materials to simplify maintenance activities ( $\mathrm{STb}$ )

With the existence of building and raw water channel, the well around the channel is always filled, because the groundwater level rises. (WOd); Strengthening the river bank embankment, thus minimizing the impact of the flood (WOc); Repair the building, so it can function as before (WOa); Improvement the building into 2 holes (channel), so it can facilitate the maintenance of the building (WOb)

Drainage Culvert of Raw

Water Infrastructure of

Repair the drainage culvert to overcome deliberate damage to dispose of flood, so building can function as before (WTa); Increasing the culvert dimension so that it

Klambu Kudu

Regulatory Door of Raw

Water Infrastructure of can pass the flood. (WTb); Improve operational and maintenance activities to minimize damage (WTc)

Klambu Kudu

Increased public participation to take part in supervising and securing buildings. (SOe); Function as a channel discharge regulator and also serve as a drain when a major flood occurs. (SOc); With regulated door, the discharge can be arranged and stable, so that the flowing discharge is not overtopping to the settlement, raising the water surface around the channel and building, so that the wells around the people always fully filled (SOd); With a good access, activity for the operation and maintenance of the building can run well (SOa); Methods, construction materials that have been obtained so that repair activities can run smoothly, so the cost of repairs can be reduced $(\mathrm{SOb})$

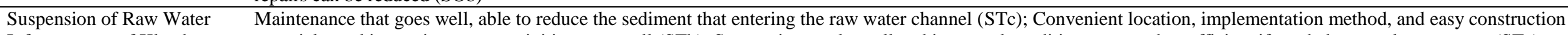
Infrastructure of Klambu

Kudu

Embankment Channel of

Raw Water Infrastructure of

Klambu Kudu

Excavation Channel of Raw

Water Infrastructure of

Klambu Kudu

Construction materials, easy construction methods strongly support channel maintenance activities, so can minimizing channel maintenance costs, such as reinforcing embankment that can minimize the damaging impact of flooding. (STc); The routine socialization that channels benefit the people around the channel and increase community participation so that the action of channel destruction can be minimized. (STd); Accessible location and good access road, strongly support channel maintenance and channel security against frequent theft. (STa); Good channel function required routine maintenance, so the water flowing relatively clear (STb)

Maintenance by routine sediment dredging, so can minimize the sediment in excavation channel, and return the channel dimension (WTa); Repair of damaged channel due to destruction and flood, thus restoring the original function, so that water entering the channel is relatively clear (WTb); Conduct periodic socialization of benefits and actions are prohibited in raw water channels (WTc) 


\section{CONCLUSIONS AND RECOMMENDATIONS}

\subsection{Conclusions}

Raw water transmission system of Klambu Kudu has not been functioning properly is because this has not been managed optimally, especially in terms of operation and maintenance. Accordingly, the actual discharge of the transmission system is not in accordance with the design discharge. By utilizing SWOT method the information about the strengths and weaknesses and the opportunities and threats of each component of the system could be provided. It can be concluded from this study that the priority of strategies are dominated by the opportunity factors to solve the problems of weaknesses (operation and maintenance, sedimentation, damage) and threats (water theft, destruction of infrastructures, flood) as well as to maximize the strength factors (condition of component, function, and accessibility).

\subsection{Recommendations}

This research only yields priority strategy of handling component of an infrastructure system. Further analysis of decision making is required to determine the priority of the transmission system components.

\section{REFERENCES}

Abbasi, H., Khanmoradi, S., Eydi, H. \& Rasekh, N., 2016. Quantitative Strategic Planning of General Office of Sports and Youth in Regard to Championship Sport Using QSPM in Kermanshah. International Journal of Sports Science, 6(2), pp. 3645.

Adib, A. \& Habib, F., 2016. Strategic planning for spatial development in the historical tissue of Yazd City with a tourism approach. European Online Journal of Natural and Social Sciences, 5(3), pp. 596605.

Akbarpour, N. \& Tabibian, M., 2015. PedestrianOriented Approaches for Improving Lost Spaces by Using SWOT (Case Study: Seyedqandan Overpass, Tehran), pp. 1-7.

Ariendi, G. T., Daryanto, A. \& Sanim, B., 2015. Strategy for Increasing Business Competitiveness of Green Property. International Journal of Innovation and Scientific Research, 19(1), pp. 24-32.

Aspan, H., Milanie, F. \& Khaddafi, M., 2015. SWOT Analysis of the Regional Development Strategy City Field Services for Clean Water Needs. International Journal of Academic Research in Business and Social Sciences, 5(16), pp. 385-397.
Baby, S., 2013. AHP Modeling for Multicriteria Decision-Making and to Optimise Strategies for Protecting Coastal Landscape Resources. International Journal of Innovation, Management, and Technology, 4(2).

BBWS Pemali Juana, 2015. Review Desain Saluran Air Baku Klambu Kudu Kabupaten Grobogan.

Bicen, H., Sadıkoğlu, S. \& Sadıkoğlu, G., 2015. The Impact of Social Networks on Undergraduate Students Learning Foreign Language. Procedia - Social and Behavioral Sciences, Volume 186, pp. 1045-1049.

Budi, I., Bhayangkara, W. D. \& Fadah, I., 2016. Identification of Problems and Strategies of the Home-Based Industry in Jember Regency. Agriculture and Agricultural Science Procedia, Vol. 9, pp. 363 370 .

Coman, A. \& Ronen, B., 2009. Focused SWOT: Diagnosing critical strengths and weaknesses. International Journal of Production Research, 47(20), pp. 5677-5689.

David, F. R., 2011. Strategic management: Concepts and cases,: Prentice Hall.

David, M. E., David, F. R. \& David, F. R., 2017. The quantitative strategic planning matrix: a new marketing tool. Journal of Strategic Marketing, 25(4), pp. 342-352.

Diamantopoulou, P. \& Voudouris, K., 2008. Optimization of water resources management using SWOT analysis: the case of Zakynthos Island, Ionian Sea, Greece. Environmental Geology, 54(1), pp. 197211.

Ekmekcioglu, M., Kutlu, A. C. \& Kahraman, C., 2011. A Fuzzy Multi-Criteria SWOT Analysis: An Application to Nuclear Power Plant Site Selection. International Journal of Computational Intelligence Systems, 4(4), pp. 583-595.

Eshaghi, A., Mousavi, S. \& Eshaghi, A., 2015. The application of SWOT model to compile appropriate strategies for projects risk management in Fooladtechnic International Company. Science Journal of Business and Management, 3(1), p. 26.

Gallego-Ayala, J. \& Juizo, D., 2011. Strategic implementation of integrated water resources management in Mozambique: An A'WOT analysis. Physics and Chemistry of the Earth, 36(14-15), pp. 1103-1111. 
Ghosian, A., Ebadi, M. \& Shojazadeh, A., 2015. The Quantitative Strategic Planning Matrix (QSPM) Applied To Sport in West Azerbaijan Province. International Journal of Sport Studies, 5(1), pp. 124128.

Hartley, J., 2014. Some thoughts on Likert-type scales. International Journal of Clinical and Health Psychology, 14(1), pp. 83-86.

Helms, M. M. \& Nixon, J., 2010. Exploring SWOT analysis--where are we now? A review of academic research from the last decade. Journal of Strategy and Management, 3(3), pp. 215-251.

Hezarjribi, H. N. \& Bozorgpour, Z., 2017. Optimized Business Management by Using SWOT and QSPM Matrices (Case Study: Mazandaran Wood and Paper Industries) H.N. Journal of Administrative Management, Education and Training, 13(1), pp. 409422.

Jasiulewicz-Kaczmarek, M., 2016. SWOT analysis for Planned Maintenance strategy-a case study. IFACPapersOnLine, 49(12), pp. 674-679.

Kallioras, A., Pliakas, F., Diamantis, I. \& Kallergis, G., 2010. SWOT analysis in groundwater resources management of coastal aquifers: a case study from Greece. Water International, 35(4), pp. 425-441.

Likert, R. A., 1932. A Technique for Measurement of Attitudes. Archives of Psychology, Volume 22.

Mainali, B. et al., 2011. SWOT analysis to assist identification of the critical factors for the successful implementation of water reuse schemes. Desalination and Water Treatment, 32(1-3), pp. 297-306.

Malik, A. S., Al Kahtani, S. N. \& Naushad, M., 2013. Integrating AHP, SWOT and QSPM in strategic planning- an application to college of business administration in Saudi Arabia. International Journal of Academic Research, 5(5), pp. 373-379.

Martínez, C. I. \& Piña, W. H. A., 2015. Recycling in Bogotá : A SWOT Analysis of Three Associations to Evaluate the Integrating the Informal Sector into Solid Waste Management. International Journal of Social, Behavioral, Educational, Economic and Management Engineering, 9(6), pp. 1668-1673.

Matias, N. G., 2010. Catchment residents-based SWOT analysis of a reservoir ecosystem for sustainable water management: A case study from the region of Alentejo, Portugal. Water Quality Research Journal of Canada, 45(3), pp. 295-306.
Michailidis, A. et al., 2015. Exploring Treated Wastewater Issues Related to Agriculture in Europe, Employing a Quantitative SWOT Analysis. Procedia Economics and Finance, 33(15), pp. 367-375.

Mohammadi, J., Masoudian, A. \& Kanani, M., 2015. Developing a Water Management Model for Esfahan Metropolis within the Framework of Green City Approach. Mediterranean Journal of Social Sciences, 6(6), pp. 532-541.

Mousavi, S. N. \& Akbari, M. R., 2012. Internal and external strategic analysis of poultry cooperatives in Fars Province. Journal of Development and Agricultural Economics, 4(5), pp. 119-124.

Mousavizadeh, S. R., Khorrami, S. \& Bahreman, M., 2015. International Journal of Operations and Logistics Presenting a Strategic Plan of Integrated Water Resources Management by using SWOT in Bushehr Province. International Journal of Operations and Logistics Management, 4(1), pp. 2742.

Nagara, G. et al., 2015. Comparative SWOT Analysis for Water Solutions in Asia and Africa. Water Resources Management, 29(1), pp. 125-138.

Nejad, M. B., Pouyan, N. \& Shojaee, M. R., 2011. Applying Topsis and Qspm Methods in Framework Swot Model : Case Study of the Iran' S Stock Market. Australian Journal of Business and Management Research, 1(5), pp. 93-104.

Ololube, N. P., 2016. Education Fund Misappropriation and Mismanagement and the Provision of Quality Higher Education in Nigeria. International Journal of Scientific Research in Education, Volume 9.

Ommani, A. R., 2011. Strengths, weaknesses, opportunities and threats (SWOT) analysis for farming system businesses management: Case of wheat farmers of Shadervan District, Shoushtar Township, Iran. African Journal of Business Management, 5(22), pp. 9448-9454.

Othman, H. et al., 2012. Student's Perceptions on Benefits Gained from Cooperative Learning Experiences in Engineering Mathematics Courses. Procedia - Social and Behavioral Sciences, 60(Supplement C), pp. 500-506.

Patel, R. \& Patel, S., 2016. Water Losses in Canal Networking (Narmada Canal Section Near Gandhinagar-Ahmedabad). 2(7), pp. 186-189. 
Petousi, I. et al., 2017. Assessment of Water Management measures through SWOT Analysis: The case of Crete Island, Greece. International Journal of Environmental Science, Volume 2, pp. 59-622.

Prisanto, D. E., Yanuwiadi, B. \& Soemarno, 2015. Studi Pengelolaan IPAL ( Instalasi Pengolahan Air Limbah ) Domestik Komunal di Kota Blitar , Jawa Timur. 6(1), pp. 74-80.

Rehak, D. \& Grasseova, M., 2011. The Ways of Assessing the Security of Organization Information Systems through SWOT Analysis.

Rezazadeh, S., Jahani, A., Makhdoum, M. \& Meigooni, H. G., 2017. Evaluation of the Strategic Factors of the Management of Protected Areas Using SWOT Analysis-Case Study: Bashgol Protected Area-Qazvin Province. Evaluation of the Strategic Factors of the Management of Protected Areas Using SWOT Analysis-Case Study: Bashgol Protected Area-Qazvin Province, 7(1), pp. 55-68.

Rumanti, A. A. \& Syauta, K. J., 2013. Determining Strategies Based on Strategic Position Analysis in Small and Medium Enterprises. International Journal of Information and Education Technology, 3(4), pp. $442-447$.

Saghaei, M., 2012. Strategic Planning for A Lubricant Manufacturing Company Using Swot Analysis, QSPM model (one of the Top companies of Iranian Oil, Gas and Petrochemical Products Exporters' Association). Australian Journal of Business and Management Research, 1(10), pp. 18-24.

Sappaile, B. I., 2007. Pembobotan Butir Pernyataan Dalam Bentuk Skala Likert Dengan Pendekatan Distribusi Z. Jurnal Pendidikan Dan Kebudayaan, 13(64), pp. 1-8.

Sargolzaei, N. M. \& Keshtegar, A., 2013. An analysis of human resource strategic planning in Zahedan University of Medical Sciences by applying SWOT model. European Online Journal of Natural and Social Sciences, 2(3), pp. 1198-1201.

Shafieyan, M., Homayounfar, M. \& Fadaei, M., 2017. Identification of Strategies for Sustainable Development of Rice Production in Guilan Province Using SWOT Analysis. International Journal of Agricultural Management and Development (IJAMAD), 7(2), pp. 141-153.

Shiehbeiki, S. et al., 2014. Public participation role in sustainable urban management by quantitative strategic planning matrix (QSPM). International
Journal of Environmental Research, 8(4), pp. 13091314.

Srdjevic, Z., Bajcetic, R. \& Srdjevic, B., 2012. Identifying the Criteria Set for Multicriteria Decision Making Based on SWOT/PESTLE Analysis: A Case Study of Reconstructing A Water Intake Structure. Water Resources Management, 26(12), pp. 33793393.

Tehrani, M. M. E., 2017. Analyzing Strategic Factors Associated with Issuance of Environmental Liability Insurance Policy in Developing Countries using SWOT and QSPM. International Journal of Environmental Science and Development, 8(5), pp. 359-365.

Troch, F. et al., 2015. BRAIN TRAINS: Intermodal rail freight transport and hinterland connections $A$ SWOT analysis to assess the Belgian rail practice.

Valiollarabieifar, et al., 2014. Stability monitoring of the social structure of urban housing, with using SWOT QSPM technique. Scholars Journal of Arts, Humanities and Social Sciences, Vol. 2, pp. 362-371.

Wahyuningsih, T., 2016. The Development Strategy of Main Commodities of Rice in Buru District, Maluku. World Journal of Agricultural Research, 4(1), pp. 9-17.

Wang, X. P., Zhang, J. \& Yang, T., 2014. Hybrid SWOT approach for strategic planning and formulation in china worldwide express mail service. Journal of Applied Research and Technology, 12(2), pp. 230-238.

Wati, N., Siswoyo, B. \& Wardana, L., 2016. Development Strategy of Mangrove Conservation And Ecotourism BeejayBakau Resort. IOSR Journal of Business and Management, 18(5), pp. 116-122.

Whalley, A., 2010. Strategic Marketing.

Widhiarso, W., 2011. Aplikasi Teori Respon Butir untuk Menguji Invariansi Pengukuran Psikologi untuk Keperluan Survei dan Seleksi Pekerjaan. Psikobuana, 3(2), pp. 103-117.

Widiyanti, N. M. N. Z., 2016. Kinerja Usahatani dan Motivasi Petani dalam Penerapan Inovasi Varietas Jagung Hibrida pada Lahan Kering di Kabupaten Lombok Timur. Jurnal Penyuluhan Pertanian.

Wijayanto, D., 2016. Fisheries Development Strategies of Biak Numfor Regency, Indonesia. Aquatic Procedia, Volume 7, pp. 28-38. 
Windiyani, T., 2012. Instrumen Untuk Menjaring Data Interval. Nominal, Ordinal Dan Data Tentang Kondisi, Keadaan, Hal Tertentu Dan Data Untuk Menjaring Variabel Kepribadian. Jurnal Pendidikan Dasar, 3(5), p. 20867433.

Yavuz, F. \& Baycan, T., 2013. Use of Swot and Analytic Hierarchy Process Integration as a
Participatory Decision Making Tool in Watershed Management. Procedia Technology, 8(Haicta), pp. 134-143. 